\section{Amount and distribution of coarse woody debris in pine ecosystems of north-western Spain, Russia and the United States}

\author{
Celia Herrero $^{(1)}$, Olga Krankina ${ }^{(2)}$, Vicente J Monleon ${ }^{(3)}$, Felipe Bravo ${ }^{(1)}$
}

The quantity and characteristics of coarse woody debris (CWD) were examined in four distinct pine ecosystems of north-western (NW) Spain, NW Russia and the NW USA. The average CWD volume and biomass ranged from $3.76 \mathrm{~m}^{3} \mathrm{ha}^{-1}$, $1.55 \mathrm{Mg} \mathrm{ha}{ }^{-1}$ in pine plantations in NW Spain to $24.86 \mathrm{~m}^{3} \mathrm{ha}^{-1}, 6.69 \mathrm{Mg} \mathrm{ha}^{-1}$ in Scots pine forest in NW Russia to $55.35 \mathrm{~m}^{3} \mathrm{ha}^{-1}, 20.38 \mathrm{Mg} \mathrm{ha}^{-1}$ and $77.04 \mathrm{~m}^{3}$ $\mathrm{ha}^{-1}, 28.84 \mathrm{Mg} \mathrm{ha}^{-1}$ in ponderosa and lodgepole pine forests in the NW USA. Despite differences in species, ecological conditions and management histories, in all four ecosystems the mean snag volume was less than that of logs, most of the CWD mass was in an intermediate degree of decay, and mature stands had the greatest amount of CWD mass, followed by middle-age and then young stands. The CWD ratio (ratio of dead to live wood volume) ranged from $2.8 \%$ to $126.6 \%$, depending on pine ecosystem and stand age, and was influenced by the type of natural and human disturbance. The difference in CWD amount and distribution among the regions studied reflected differences in disturbance history and management practices. Only in NW USA was the sample size large enough to examine the effect of disturbance type on CWD amount and distribution. There, fire and insect damage were found to considerably influence the amount of CWD in both lodgepole and ponderosa pine forests. Comparison of how different factors affect the amount and distribution of CWD in different ecosystems could be useful in developing ecologically sustainable forest management guidelines.

Keywords: Disturbance, Lodgepole Pine, Dead Wood, Ponderosa Pine, Scots Pine

\section{Introduction}

Coarse woody debris (CWD) is one of the most important functional and structural components of forest ecosystems (Harmon et al. 1986, McComn \& Lindenmayer 1999). CWD affects nutrient cycling, carbon storage and hydrological processes. It also serves as an essential substrate for a multitude of species, including numerous rare and endangered species (von Oheimb et al. 2007).

Numerous studies have examined the role of CWD in maintaining biodiversity (Esseen et al. 1997, Angelstam 1998), estimating the decomposition rates of many important tree species (Yatskov et al. 2003), evaluating the effect of CWD in carbon and nutrient cycles (Krankina et al. 1999, Hyvonenn et al. 2000, Merganicôvá \& Merganic 2010) and analyzing the quantity, structure and dynamics of CWD in managed and unmanaged forests (Green \& Peterken 1997, Linder et al. 1997, Siitonen et al. 2000, Lombardi et al. 2008). In unmanaged forests, the amount of CWD is the result of tree mortality and dead wood decay rates, both of which are affected by climate, site productivity, tree species com- $\square$ (1) Sustainable Forest Management Research Institute, Uva-INIA, University of Valladolid, Avda. Madrid 44, C.P. 34071 Palencia (Spain); (2) Department of Forest Science, Oregon State University, 321 Richardson Hall, 97331 Corvallis, Oregon (USA); (3) USDA Forest Service, Pacific Northwest Research Station, 3200 Jefferson Way, 97331 Corvallis, Oregon (USA)

@ Celia Herrero de Aza (chdeaza@pvs.uva.es)

Received: May 21, 2012 - Accepted: Jul 28, 2013

Citation: Herrero C, Krankina O, Monleon VJ, Bravo F, 2014. Amount and distribution of coarse woody debris in pine ecosystems of north-western Spain, Russia and the United States. iForest 7: 53-60 [online 2013-10-28] URL: http://www.sisef.it/iforest/contents/? id=ifor0644-006

Communicated by: Renzo Motta position, disturbance regime, previous forest stand characteristics and the successional stage of the forest (Harmon et al. 1986, Spies et al. 1988). In managed forests, CWD quantities are typically kept very low, to avoid pest problems and fire hazards and to maximize the commercial value of the harvest. Where economics and accessibility allow, trees affected by insects, diseases, and fire are usually removed immediately, before they die or deteriorate (DeBell et al. 1997, Green \& Peterken 1997). Plantation forests are typically managed on short rotations and are generally subject to intensive harvesting methods, resulting in structurally homogenous stands without significant amounts of CWD (Harmon et al. 1986, deMaynadier \& Hunter 1995). However, silvicultural activities such as thinning, pruning and harvesting can create woody debris (Carlyle 1995). The increasing importance of biodiversity and carbon storage favors the maintenance and promotion of CWD in managed forests. Leaving some live and dead trees during logging operations, or even killing trees to create CWD, are some of the operational means for meeting biodiversity needs in managed forests (Esseen et al. 1997).

The amount and distribution of CWD can be a criterion for assessing and determining baseline silvicultural practices. This type of data is available for different types of forests, but the geographic extent and focus of most studies is limited to one or a few specific stands. There is very little information on continental or global CWD quantities and distribution patterns or on how management affects these patterns. Comparison of different forest ecosystems makes it possible to examine the effects of site productivity and stand structure on CWD amounts and decomposition rates. It also improves understanding of how different management practices affect CWD as a resource, which is vital to formulating guidelines and strategies for increasing carbon storage on forest lands. In light of this information gap, the aim of this paper was to quantify the amount, quality and distribution of CWD in four pine ecosystems in NW Spain, NW Russia and NW USA: three diverse geographical locations with different species and histories of human activity and disturbance. In NW Spain, we find relatively young, actively managed and moderately productive plantations. Even-age silvicultural management is typically used on public lands in this region and consists of clearcutting followed by natural regeneration, pre-commercial thinning and a low thinning regime when economically feasible. Previous research has indicated that thinning increased CWD abundance in this area (Herrero et al. 2010). Forestry in NW Russia is characterized by an established, relatively long rotation system with 
few natural stands remaining. Disturbances are frequent and windthrow fairly widespread (Krankina \& Harmon 1995). Clearcutting followed by natural regeneration has been the dominant silvicultural system in this region. However, the current trend is toward more site-specific approaches that favor partial cutting or cutting and regeneration, with methods that recognize forest peculiarities and environmental conditions. Finally, NW USA features a relatively recent initial expansion of timber harvesting in previously unmanaged forests where natural disturbance regimes continue to play a major role, in addition to forests that have never been managed. The current landscape is a mixture of different conditions including managed stands, protected areas, and second growth forests that originated after extensive harvesting in the 1920's. Of particular importance has been the suppression of the natural, low-severity fire regime that favored fire-tolerant species and kept tree density low (Hessburg et al. 2005). Current forests are affected by natural disturbances such as fire or damage from insect plagues and diseases. The three regions are representative of typical land-use histories throughout the world, which are assumed to influence CWD stores.

This study was structured around the following specific objectives: (1) to quantify the amount of CWD in the different pine ecosystems; (2) to study CWD distribution among decay classes and stand ages; and (3) to determine the impact of natural and human disturbances on CWD in NW USA pine ecosystems.

\section{Material and methods}

\section{Study areas}

The first study region was located in NW Spain $\left(42^{\circ} \mathrm{N}, 4^{\circ} \mathrm{W}\right)$ at an altitude of 800 $1000 \mathrm{~m}$ a.s.l. It is a transitional area between forest and cropland, with low mountains and valleys. The Mediterranean climate features long, cold winters and warm, dry summers. January temperatures range between $-2{ }^{\circ} \mathrm{C}$ and $6{ }^{\circ} \mathrm{C}$, July temperatures between $9{ }^{\circ} \mathrm{C}$ and $21{ }^{\circ} \mathrm{C}$, and mean annual rainfall is 633 $\mathrm{mm}$. Soils are mainly acidic, with some neutral soil and limestone areas (Oria de Rueda et al. 1996). Forest covers 61570 ha $(33.0 \%)$ of the total area. Thanks to an extensive plantation program that started in the 1970 s, pine stands cover $41.5 \%$ of the total forested area. The three main species are Scots pine (Pinus sylvestris L. - 43.6\%), black pine (Pinus nigra Arn. - 43.9\%) and maritime pine (Pinus pinaster Ait. - 12.5\%). Plantations are typically a mixture of these three species, with homogeneous 30 to 60 year-old stands managed for wood production.

The second study area was situated on the
East-European plain in the St. Petersburg region of NW Russia $\left(58-61^{\circ} \mathrm{N}, 29-34^{\circ} \mathrm{E}\right)$, at an elevation range of $0-250 \mathrm{~m}$ a.s.l. The cool maritime climate features wet summers and long, cold winters. July mean temperatures are $16-17{ }^{\circ} \mathrm{C}$, January minimum temperatures range from -7 to $-11{ }^{\circ} \mathrm{C}$ and mean annual precipitation is $700 \mathrm{~mm}$. The flat terrain rests on ancient sea sediment covered by a layer of moraine deposits. Soils are mostly podzols on deep loamy to sandy sediment. Forest covers $55 \%$ of this 8.1 million ha area. The natural vegetation and dominant conifer species consist mainly of southern taiga, Scots pine (Pinus sylvestris L.) and Norway spruce (Picea abies Karst.), growing in pure and mixed stands. Forest management in this region began in the $18^{\text {th }}$ century. Most forests are second-growth and harvested on a 60-120 year rotation.

The third region was located in NW USA, specifically eastern and central Oregon (42$46^{\circ} \mathrm{N}, 117-123^{\circ} \mathrm{W}$ ), and includes the eastern Cascades Range, the pumice plateau of south-central Oregon, and the Blue Mountains. Elevation of the forested areas ranges between 900 and $2000 \mathrm{~m}$ a.s.l. The climate is characterized by low summer rainfall, cold winters and a short growing season. Average January minimum temperatures range between -7 and $-11{ }^{\circ} \mathrm{C}$, average July maximum temperatures are 27 to $31^{\circ} \mathrm{C}$. The 350 to $700 \mathrm{~mm}$ of average annual precipitation falls mostly in the form of snow. Soils range from relatively young, poorly developed, mineral deficient and highly porous volcanic types to more developed basaltic types (Franklin \& Dyrness 1973). Forests in the study area were dominated by ponderosa pine (Pinus ponderosa Dougl. ex Laws) and lodgepole pine (Pinus contorta Dougl. ex Loud), which covered 2.1 and 0.8 million ha, respectively (Donnegan et al. 2008).

\section{Sampling design}

\section{NW Spain}

In NW Spain, sixty-seven plots were selected in Pinus spp. plantations on a systematic grid with a density of one plot per $2 \mathrm{~km}^{2}$. Pine plantations were grouped in two stand development stages: young ( $\leq 40$ years old) and middle-age (40-80 years old). A total of 36 plots (11 young and 25 middle-age) were located in stands that had been thinned (Tab. 1). Plots were composed of four circular subplots (15 $\mathrm{m}$ radius) joined by two perpendicular transects $50 \mathrm{~m}$ long.

Snags in the four subplots, stumps in two of the four subplots, and logs on the transects were inventoried. Snags were defined as standing dead trees with a diameter at breast height greater than $7.5 \mathrm{~cm}$. Species, height, diameter at breast height (dbh), decay class, presence of excavated cavities, azimuth and distance to plot center were recor- ded for each snag. The number, mean diameter and height of stumps in each plot were measured and recorded. Finally, line intersect sampling (LIS - Warren \& Olsen 1964) was used to estimate the log volume. Logs were defined as dead trees with a diameter greater than $7.5 \mathrm{~cm}$, either on the ground or suspended by one extreme at an inclination greater than $45^{\circ}$ from vertical. Species, diameter at the transect intersection point, length, inclination, decay class and wildlife use were recorded for each log (Forsee Project 2005). All pieces of woody debris were assigned to one of five decay classes ranging from nearly sound wood to the most advanced stages of decomposition, according to criteria described by Goodburn \& Lorimer (1998).

\section{NW Russia}

Fifty Scots pine plots were studied in NW Russia (Tab. 1), distributed among 7 different stands, ranging in age from 15 to 150 years. Of these, $38 \%$ of the plots were located in young stands ( $\leq 40$ years old), $36 \%$ in middle-age stands (40-80) and the remaining $26 \%$ in mature stands ( $>80$ years old). Eight plots (7 middle-age, 1 mature) had been thinned. The plots were also classified according to whether disturbance (windthrow) was apparent or not. Only 3 plots, all in mature stands, showed signs of disturbance.

CWD (snags, logs and stumps) was measured in fixed-area plots ranging in size from 0.2 to 1.0 ha. Within each plot, the largeand small-end diameters, length, species and decay class were recorded for each $\log >10$ $\mathrm{cm}$ in diameter and $>1 \mathrm{~m}$ in length. Stumps and snags were measured regardless of their height. Measurements varied by CWD type and condition, and were designed to characterize the volume of each piece. A detailed description of field methods can be found in Harmon \& Sexton (1996). The same fiveclass system for categorizing decay was used as in the NW Spain survey.

\section{NW USA}

Plots were located systematically by the US National Forest inventory (Bechtold \& Scott 2005) across the entire NW USA region, with approximately one plot every 4850 ha. Only plots with at least $25 \%$ of the area covered in either ponderosa pine (429 plots) or lodgepole pine (171 plots) were selected for analysis. The plot design consisted of 4 cluster points within a 1 ha circle. At each point, snags and live trees 12.7-61.0 and $>61.0 \mathrm{~cm}$ dbh were measured in a set of two nested plots measuring 0.0169 and 0.1012 ha, respectively. Species, height, diameter and decay class were recorded for each snag. Logs greater than $7.54 \mathrm{~cm}$ in diameter and $0.91 \mathrm{~m}$ in length were measured using line intersect sampling on two $17.95 \mathrm{~m}$ transects 
per point, resulting in a total transect length of $143.60 \mathrm{~m}$ per plot. Large- and small-end diameters, diameter at the point of intersection with the transect, species, decay class and length were recorded for each log. The decay class of each CWD piece was rated according to a five-class decay scale similar to that used in NW Spain and NW Russia. When distinct forest conditions were found within a plot, such as changes in ownership or forest type, they were mapped and described. Individual snags and logs were assigned to the condition where they fell. A host of other relevant variables were collected for each condition, including ownership, stand age, disturbance and management history. As in the other regions, plots were classified as young ( $\leq 40$ years old), middle-age $(40-80)$ or mature stands ( $>80$ years old). More detailed information about the field methods and sampling procedures can be found in USDA Forest Service (2007).

Stand age in the ponderosa pine forest type ranged from 1 to 350 years old. Most plots were located in middle-age $(43.6 \%)$ or mature stands $(44.5 \%)$. The plots were divided into two types: plots without apparent disturbance $(n=228)$ and plots with disturbances in the previous 10 years. A variety of disturbance types were observed: 99 plots had a history of fire (prescribed or natural, crown or ground fire), 75 plots presented insect or disease damage and 64 plots showed signs of different types of harvesting. The disturbance types were not mutually exclusive; any plot could have incurred two or more types of disturbance.

Stand age in the lodgepole pine forest type ranged from 3 to 200 years old. As with ponderosa pine forests, plots were classified as young $(\leq 40$ years old), middle-age $(40-80)$ or mature stands ( $>80$ years old) and were divided into plots without disturbances $(n=86)$ and plots with disturbances. Thirtyfour plots presented fire disturbances (prescribed or natural crown or ground fire), 48 plots had insect or disease damage and 22 plots showed signs of different types of harvesting. The frequency of disturbed plots varied according to the age category of the stand (Tab. 1).

\section{Calculation of volume and mass}

In NW Spain, snag volume $\left(\mathrm{m}^{3}\right)$ was calculated using equations from the Spanish $\mathrm{Na}-$ tional Forest Inventory (DGCN 1996). The volume of each stump was calculated using Huber's formula (Harmon \& Sexton 1996). Snag and stump volumes $\left(\mathrm{m}^{3}\right)$ were then expanded to the hectare. Log volume $\left(\mathrm{m}^{3} \mathrm{ha}^{-1}\right)$ was estimated using the following equation (Warren \& Olsen 1964, Van Wagner 1968 eqn. 1):

$$
V_{i}=\frac{\pi^{2} \sum d_{i j}^{2}}{8 L}
$$

Tab. 1 - Main characteristics of the pine ecosystems included in the study. Plots with evidence of natural disturbance are plots affected by natural disturbances such as fire, insect and disease damage or windthrow.

\begin{tabular}{llccccc}
\hline Species & Age Class & Years & $\begin{array}{c}\text { Stand } \\
\text { volume } \\
\left.\mathbf{( m}^{\mathbf{3}} \mathbf{h a}^{-1}\right)\end{array}$ & $\begin{array}{c}\text { Total } \\
\text { plots }\end{array}$ & $\begin{array}{c}\text { Thinned } \\
\text { plots }\end{array}$ & $\begin{array}{c}\text { Plots with } \\
\text { evidence of } \\
\text { natural } \\
\text { disturbance }\end{array}$ \\
\hline Pinus spp. & Young & $0-40$ & 103.14 & 25 & 11 & 0 \\
(NW Spain $)$ & Middle-age & $>40$ & 102.49 & 42 & 25 & 0 \\
\hline Pinus sylvestris & Young & $0-40$ & 63.06 & 13 & 0 & 0 \\
(NW Russia) & Middle-age & $40-80$ & 187.84 & 32 & 7 & 0 \\
& Mature & $>80$ & 415.3 & 5 & 1 & 3 \\
\hline Pinus ponderosa & Young & $0-40$ & 53.2 & 51 & 10 & 22 \\
(NW USA) & Middle-age & $40-80$ & 124.96 & 187 & 33 & 72 \\
& Mature & $>80$ & 199.18 & 191 & 21 & 80 \\
\hline Pinus contorta & Young & $0-40$ & 44.02 & 65 & 10 & 30 \\
(NW USA) & Middle-age & $40-80$ & 129.22 & 62 & 7 & 31 \\
& Mature & $>80$ & 182.31 & 44 & 5 & 21 \\
\hline
\end{tabular}

where $V_{\mathrm{i}}$ is the estimated log volume in the $i$ th plot $\left(\mathrm{m}^{3} \mathrm{ha}^{-1}\right) ; d_{\mathrm{ij}}$ the intersection diameter of the $j$-th $\log$ in the $i$-th plot $(\mathrm{cm})$; and $L$ transect length, in our case $100 \mathrm{~m}$.

In NW Russia, volume estimates were calculated from field measurements of each piece of CWD using local volume tables for intact snags and appropriate volume formulas (Newton, paraboloid, frustrum of a cone or neiloid) for other CWD conditions and types. The individual volumes were summed for each plot and plot values scaled up to obtain a value per hectare.

In NW USA, snag volume was computed using a standard set of US Forest Inventory volume equations based on diameter and height. Mean estimates of the total volume and volume per hectare were computed according to the methods of Bechtold \& Scott (2005). Log volume and mass estimates were computed using the same procedures as in NW Spain (Woodall \& Monleon 2008).

In the three regions, the CWD volume was aggregated by decay class. To estimate CWD mass, the estimated volume was multiplied by the wood bulk density. In NW Russia and NW USA, published bulk density values by species and decay class were used (Yatskov et al. 2003, Harmon et al. 2008). In Spain, bulk density was estimated by collecting 33 logs of different decay classes in the field. Large diameter, end diameter, midpoint diameter and length were measured to calculate the volume using Newton's equation (Harmon \& Sexton 1996 - eqn. 2):

$$
V_{i}=\frac{L \cdot\left(A_{b}+4 A_{m}+A_{t}\right)}{6}
$$

where $V_{\mathrm{i}}$ is the volume of the $\log , L$ is the length, and $A_{\mathrm{b}}, A_{\mathrm{m}}$ and $A_{\mathrm{t}}$ were the cross-sectional areas at the base, middle and top of the log, respectively. Dry weights of logs were determined after drying at $75{ }^{\circ} \mathrm{C}$ to constant weight. The estimated mean bulk densities (in $\mathrm{Mg} \mathrm{m}^{-3} \pm$ standard error) were
$0.441 \pm 0.075,0.351 \pm 0.079,0.281 \pm 0.101$ $0.199 \pm 0.042$ and $0.044 \pm 0.013$ for decay classes 1 through 5 , respectively.

Though standard and consistent sampling designs were applied in the three regions, there were slight differences with regard to the CWD components tallied and piece definitions. Snags, logs and stumps were measured in NW Spain and NW Russia, but only snags and logs were measured in NW USA. Additionally, the minimum size threshold used for piece definitions varied: the minimum diameter was $7.5 \mathrm{~cm}$ in NW Spain and NW USA and $10 \mathrm{~cm}$ in NW Russia. In order to assess the impact of this difference, the volume of CWD with diameters between 7.5 and $10 \mathrm{~cm}$ was calculated for NW Spain and NW USA.

For each sample plot, volume and mass of total CWD were calculated as the sum of the volume and mass of the different components (snags, logs and stumps). Averages were computed by pine ecosystem and stand age class. Only in NW USA was the sample size large enough to compute the average amount of CWD by natural (fire, insect damage) or anthropogenic (harvesting) disturbance regime. Finally, live tree volume was calculated to compute the CWD ratio (ratio of dead to live wood volume) in each plot. The CWD ratio was also calculated by age class in the three regions and by disturbance types in NW USA pine ecosystems.

\section{Statistical methods}

For each pine ecosystem, descriptive and graphical analyses of the estimated mean CWD volume and mass by components (snags, logs and stumps), decay class, age class and disturbance type were examined. To determine statistically significant differences in volume and mass of CWD, logs, snags and stumps, a linear mixed model (LMM) was used for the following factors and their interactions: pine ecosystem with 

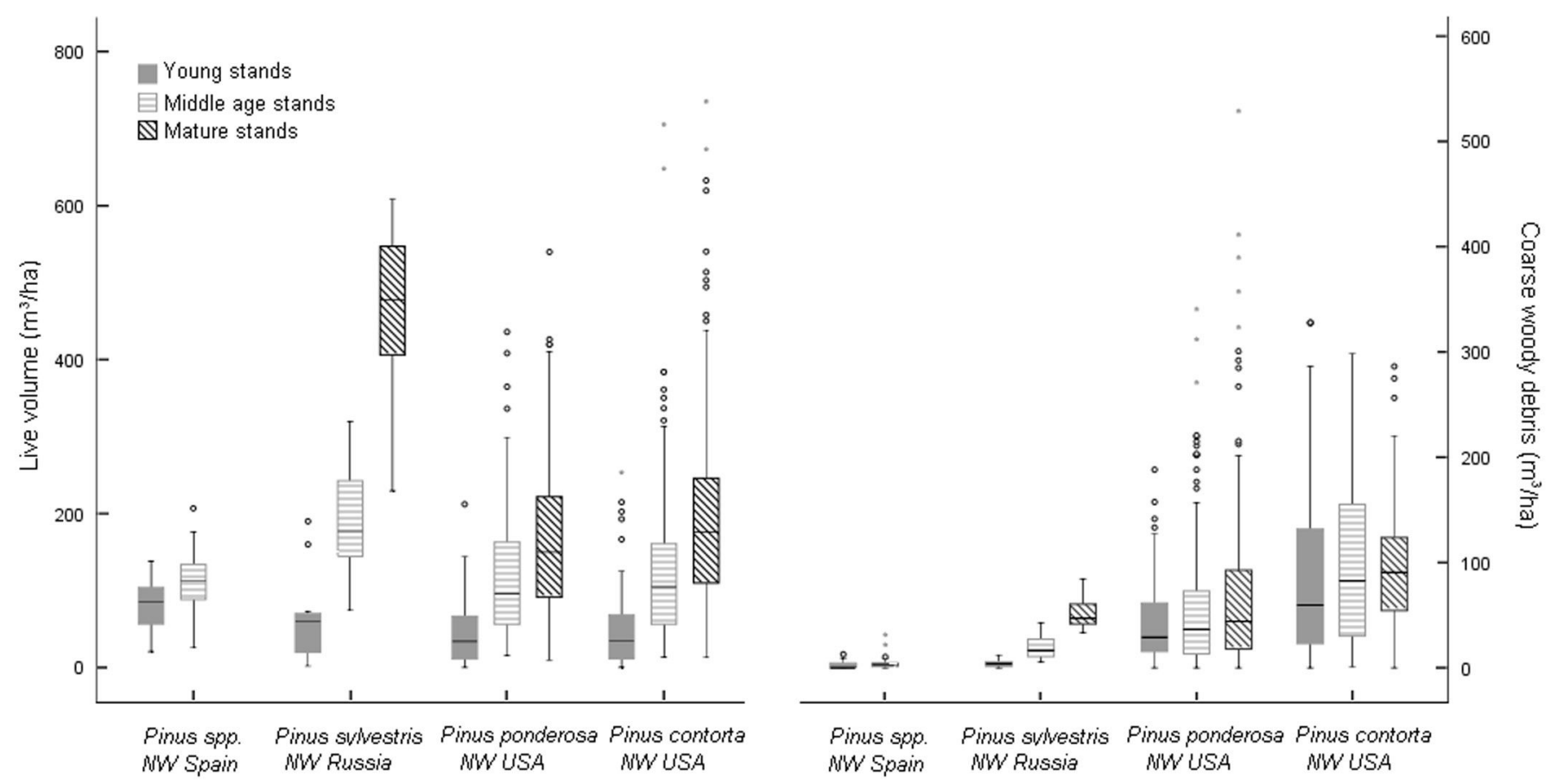

Fig. 1 - Live and CWD volume by pine ecosystem and age class. Distribution of live and coarse woody debris volume by pine ecosystem and age class.

four levels: 1 (pine plantations in NW Spain), 2 (Scots pine in NW Russia), 3 (ponderosa pine in NW USA), and 4 (lodgepole pine in NW USA); age class with three levels: 1 (young stands), 2 (middle-age stands) and 3 (mature stands). Only two pine ecosystem levels (NW Spain and NW Russia) were used for the analysis of stump volume and mass. The LMM allowed us to correct the heteroscedasticity of variance caused by the pine ecosystem factor. Differences among age classes in each pine ecosystem were evaluated by individual contrasts. The SAS 9.1 PROC MIXED statistical program was used for the analyses (SAS Institute Inc 2010).

\section{Results}

There were significant differences $(p<0.0001)$ in the volume and biomass of logs and snags among pine ecosystems, age classes and the interaction between the two factors. The stump pool showed significant differences among age classes in pine ecosystems of NW Spain and NW Russia $(\mathrm{p}<0.0002)$.

The amount of CWD varied greatly between pine ecosystems (Fig. 1). The CWD averages in plots without recorded disturbances ranged from $3.76 \mathrm{~m}^{3} \mathrm{ha}^{-1}(1.55 \mathrm{Mg}$ $\mathrm{ha}^{-1}$ ) in pine plantations in NW Spain to $77.04 \mathrm{~m}^{3} \mathrm{ha}^{-1}\left(28.84 \mathrm{Mg} \mathrm{ha}^{-1}\right)$ in lodgepole pine in NW USA (Tab. 2). Between these two extremes, $24.86 \mathrm{~m}^{3} \mathrm{ha}^{-1}\left(6.69 \mathrm{Mg} \mathrm{ha}^{-1}\right)$ was estimated for Scots pine in NW Russia and $55.35 \mathrm{~m}^{3} \mathrm{ha}^{-1}\left(20.38 \mathrm{Mg} \mathrm{ha}^{-1}\right)$ for ponderosa pine in NW USA. CWD distribution by decay class also varied among pine ecosystems $(p<0.0001$ - Fig. 2). In the NW Spain plantations, decay class 1 material was the most abundant due to recent thinning, and mass in decay classes 3-5 was the scar-

Tab. 2 - CWD volume and mass for logs, snags and stumps by age class and pine ecosystem. Letters indicate statistically significant diffe rences among age classes $(p<0.05)$ within each pine ecosystem evaluated with individual contrasts. CWD ratio is the ratio of dead to live wood volume.

\begin{tabular}{|c|c|c|c|c|c|c|c|c|c|c|c|}
\hline \multirow[b]{2}{*}{ Species } & \multirow{2}{*}{$\begin{array}{l}\text { Age } \\
\text { Class }\end{array}$} & \multicolumn{2}{|c|}{ Log } & \multicolumn{2}{|c|}{ Snag } & \multicolumn{2}{|c|}{ Stump } & \multicolumn{2}{|c|}{ Total CWD } & \multirow{2}{*}{$\begin{array}{c}\text { Live } \\
\text { volume } \\
\left(\mathrm{m}^{3} \mathrm{ha}^{-1}\right)\end{array}$} & \multirow{2}{*}{$\begin{array}{c}\text { CWD } \\
\text { ratio } \\
(\%)\end{array}$} \\
\hline & & $\begin{array}{c}\text { Volume } \\
\left(\mathrm{m}^{3} \mathrm{ha}^{-1}\right)\end{array}$ & $\begin{array}{c}\text { Mass } \\
\left(\mathrm{Mg} \mathrm{ha}^{-1}\right)\end{array}$ & $\begin{array}{c}\text { Volume } \\
\left(\mathrm{m}^{3} \mathbf{h a}^{-1}\right)\end{array}$ & $\begin{array}{c}\text { Mass } \\
\left(\text { Mg ha }^{-1}\right)\end{array}$ & $\begin{array}{c}\text { Volume } \\
\left(\mathrm{m}^{3} \mathrm{ha}^{-1}\right)\end{array}$ & $\begin{array}{c}\text { Mass } \\
\left(\text { Mg ha }^{-1}\right)\end{array}$ & $\begin{array}{c}\text { Volume } \\
\left(\mathrm{m}^{3} \mathrm{ha}^{-1}\right)\end{array}$ & $\begin{array}{c}\text { Mass } \\
\left(\text { Mg ha }^{-1}\right)\end{array}$ & & \\
\hline \multirow{3}{*}{$\begin{array}{l}\text { Pinus spp. } \\
\text { (NW Spain) }\end{array}$} & All & 1.28 & 0.49 & 1.04 & 0.43 & 1.44 & 0.63 & 3.76 & 1.55 & 102.73 & 3.66 \\
\hline & Your & $0.68^{a}$ & $0.29^{\mathrm{a}}$ & $0.83^{\mathrm{a}}$ & $0.34^{\mathrm{a}}$ & $1.12^{\mathrm{a}}$ & $0.49^{\mathrm{a}}$ & $2.64^{\mathrm{a}}$ & $1.12^{\mathrm{a}}$ & $103.14^{\mathrm{a}}$ & $2.56^{\mathrm{a}}$ \\
\hline & Middle-age & $1.64^{\mathrm{a}}$ & $0.61^{\mathrm{a}}$ & $1.17^{\mathrm{a}}$ & $0.48^{\mathrm{a}}$ & $1.62^{\mathrm{a}}$ & $0.71^{\mathrm{a}}$ & $4.43^{\mathrm{a}}$ & $1.62^{\mathrm{a}}$ & $102.49^{b}$ & $4.32^{\mathrm{a}}$ \\
\hline \multirow{4}{*}{$\begin{array}{l}\text { Pinus sylvestris } \\
\text { (NW Russia) }\end{array}$} & All & 15.16 & 3.70 & 8.41 & 2.77 & 1.29 & 0.22 & 24.86 & 6.69 & 248.31 & 10.01 \\
\hline & Young & $1.31^{\mathrm{a}}$ & $0.25^{\mathrm{a}}$ & $1.78^{\mathrm{a}}$ & $0.51^{\mathrm{a}}$ & $0.84^{\mathrm{a}}$ & $0.15^{\mathrm{a}}$ & $3.94^{\mathrm{a}}$ & $0.91^{\mathrm{a}}$ & $63.06^{\mathrm{a}}$ & $6.25^{\mathrm{a}}$ \\
\hline & Middle-age & $11.30^{\mathrm{b}}$ & $2.90^{\mathrm{b}}$ & $7.05^{b}$ & $2.31^{\mathrm{b}}$ & $0.87^{\mathrm{a}}$ & $0.15^{\mathrm{a}}$ & $19.22^{b}$ & $5.36^{\mathrm{b}}$ & $187.84^{b}$ & $10.23^{\mathrm{a}}$ \\
\hline & Mature & $32.04^{\mathrm{c}}$ & $7.71^{\mathrm{c}}$ & $15.88^{\mathrm{c}}$ & $5.29^{\mathrm{c}}$ & $2.20^{\mathrm{a}}$ & $0.37^{\mathrm{a}}$ & $50.13^{c}$ & $13.38^{\mathrm{c}}$ & $460.18^{c}$ & $10.89^{\mathrm{a}}$ \\
\hline \multirow{4}{*}{$\begin{array}{l}\text { Pinus ponderosa } \\
\text { (NW USA) }\end{array}$} & All & 45.29 & 17.46 & 10.06 & 2.91 & - & - & 55.35 & 20.38 & 141.24 & 39.19 \\
\hline & Youn & $39.33^{\mathrm{a}}$ & $15.07^{\mathrm{a}}$ & $2.33^{\mathrm{a}}$ & $0.52^{\mathrm{a}}$ & - & - & $41.66^{\mathrm{a}}$ & $15.59^{\mathrm{a}}$ & $62.59^{\mathrm{a}}$ & $66.56^{\mathrm{a}}$ \\
\hline & Middle-age & $42.57^{\mathrm{a}}$ & $16.49^{\mathrm{a}}$ & $5.68^{\mathrm{a}}$ & $1.38^{\mathrm{a}}$ & - & - & $48.24^{\mathrm{a}}$ & $17.87^{\mathrm{a}}$ & $116.45^{b}$ & $41.43^{b}$ \\
\hline & Mature & $49.98^{\mathrm{a}}$ & $19.22^{\mathrm{a}}$ & $17.07^{\mathrm{b}}$ & $5.27^{\mathrm{b}}$ & - & - & $67.04^{b}$ & $24.49^{\mathrm{b}}$ & $191.03^{\mathrm{c}}$ & $35.09^{b}$ \\
\hline \multirow{4}{*}{$\begin{array}{l}\text { Pinus contorta } \\
\text { (NW USA) }\end{array}$} & All & 67.23 & 25.67 & 9.81 & 3.18 & - & - & 77.04 & 28.84 & 117.31 & 65.67 \\
\hline & Youn & $54.23^{\mathrm{a}}$ & $20.70^{\mathrm{a}}$ & $5.28^{\mathrm{a}}$ & $1.50^{\mathrm{a}}$ & - & - & $59.51^{\mathrm{a}}$ & $22.20^{\mathrm{a}}$ & $47.00^{\mathrm{a}}$ & $126.62^{\mathrm{a}}$ \\
\hline & Middle-age & $71.90^{\mathrm{a}}$ & $27.41^{\mathrm{a}}$ & $10.66^{\mathrm{a}}$ & $3.65^{\mathrm{a}}$ & - & - & $82.56^{\mathrm{a}}$ & $31.06^{\mathrm{a}}$ & $138.80^{\mathrm{b}}$ & $59.48^{\mathrm{a}}$ \\
\hline & Mature & $82.58^{\mathrm{a}}$ & $31.56^{\mathrm{a}}$ & $16.13^{\mathrm{a}}$ & $5.32^{\mathrm{a}}$ & - & - & $98.72^{\mathrm{a}}$ & $36.88^{\mathrm{a}}$ & $205.02^{\mathrm{c}}$ & $48.15^{\mathrm{a}}$ \\
\hline
\end{tabular}


cest. In NW Russia, CWD mass for Scots pine was greatest in decay classes 1,2 and 3 . Ponderosa and lodgepole pine ecosystems in NW USA showed a relatively homogeneous CWD mass distribution across decay classes. For all regions, log volume was higher than snag volume, especially in NW USA, where $\log$ volume was 1.8 times greater than that of snags in both forest types (Tab. 2). Examination by decay class showed the same pattern.

The interaction between pine ecosystem and age class was also statistically significant, indicating that CWD and component distribution by age class differed among pine ecosystems. Most individual contrasts showed a statistically significant higher amount of CWD in older stands. In general, the greatest amount of total CWD was found in mature stands, followed by middle-age and then young stands (Tab. 2). In NW USA however, although the total amount of live volume was greatest in the oldest age classes (Fig. 1), the CWD ratio was greatest in young stands (Tab. 2). This suggests a legacy effect from past disturbances. For several decay classes of the NW USA forest ecosystems there was more CWD in middle-age stands than in mature stands (Tab. 3). Large amounts of CWD were found in recently disturbed ponderosa pine areas, mainly due to

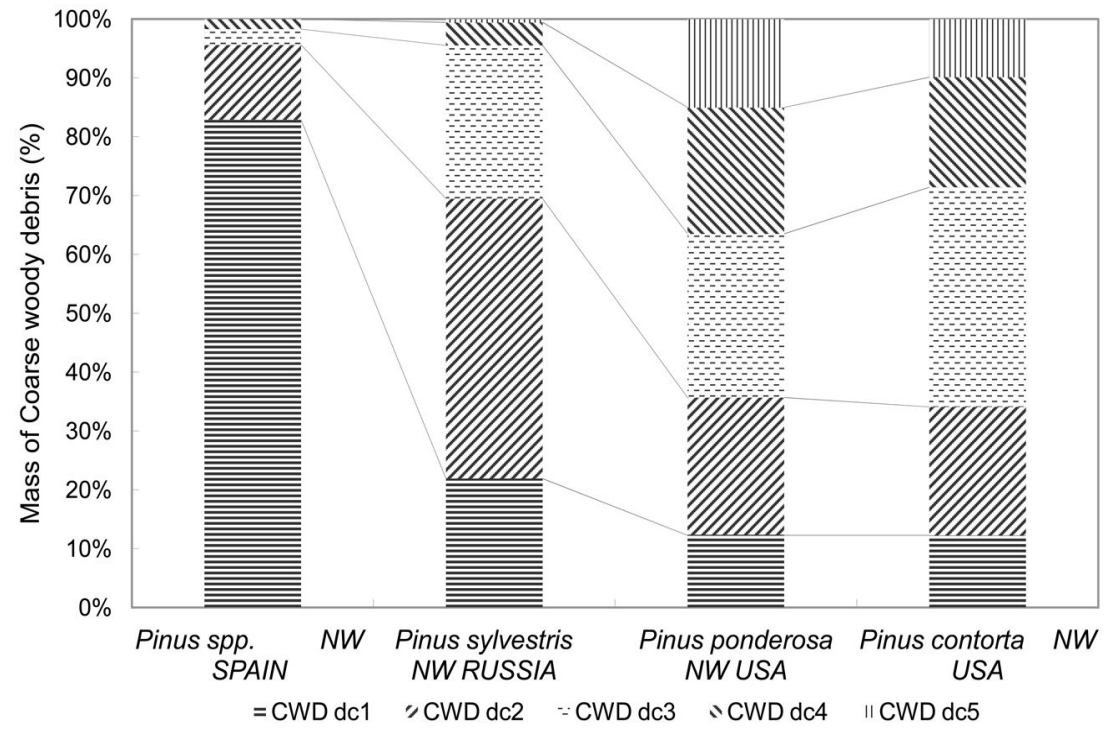

Fig. 2 - Mass by decay class. Percentage CWD mass by decay class in the different pine ecosystems. CWD de $i$ is the mass of CWD in decay class $i$.

insect and disease damage and harvesting but more so in young stands.

(Fig. 3). Young stands had the highest log The role of disturbance was difficult to volume $\left(97.05 \mathrm{~m}^{3} \mathrm{ha}^{-1}\right)$. The CWD ratio in compare across regions because the sample lodgepole pine stands with evidence of fire size for disturbed plots was insufficient in all disturbance was very large in all age classes, regions except NW USA. However, results

Tab. 3 - Log and snag mass in the different decay classes by age class and pine ecosystem. dc1 to dc5 are the decay class level ranges from $1=$ nearly sound wood with bark intact to $5=$ the most advanced stages of decomposition.

\begin{tabular}{|c|c|c|c|c|c|c|c|c|c|c|c|}
\hline \multirow{2}{*}{ Species } & \multirow{2}{*}{ Age Class } & \multicolumn{5}{|c|}{$\log$ mass $\left(\mathrm{Mg} \mathrm{ha}^{-1}\right)$} & \multicolumn{5}{|c|}{ Snag mass $\left(\mathrm{Mg} \mathrm{ha}^{-1}\right)$} \\
\hline & & dc1 & dc2 & dc3 & dc4 & de5 & dc1 & dc2 & dc3 & dc4 & de5 \\
\hline \multirow{5}{*}{$\begin{array}{l}\text { Pinus spp. } \\
\text { (NW Spain) } \\
\text { Pinus sylvestris } \\
\text { (NW Russia) }\end{array}$} & Young & 0.24 & 0.05 & 0 & 0 & 0 & 0.24 & 0.1 & 0 & 0 & 0 \\
\hline & Middle-age & 0.39 & 0.12 & 0.06 & 0.04 & 0 & 0.37 & 0.1 & 0.01 & 0 & 0 \\
\hline & Young & 0 & 0.01 & 0.19 & 0.04 & 0.01 & 0.17 & 0.29 & 0 & 0.05 & 0 \\
\hline & Middle-age & 0.04 & 0.98 & 1.85 & 0.03 & 0 & 0.93 & 1.22 & 0.16 & 0 & 0 \\
\hline & Mature & 0.72 & 4.08 & 2.32 & 0.54 & 0.07 & 2.45 & 2.7 & 0.14 & 0 & 0 \\
\hline \multirow{3}{*}{$\begin{array}{l}\text { Pinus ponderosa } \\
\text { (NW USA) }\end{array}$} & Young & 0.24 & 1.46 & 5.17 & 4.35 & 3.85 & 0.25 & 0.2 & 0.05 & 0.02 & 0.01 \\
\hline & Middle-age & 0.48 & 3.67 & 4.96 & 4.45 & 2.94 & 0.59 & 0.4 & 0.09 & 0.26 & 0.03 \\
\hline & Mature & 2.07 & 4.77 & 5.7 & 3.95 & 2.72 & 2.60 & 1.64 & 0.78 & 0.06 & 0.18 \\
\hline \multirow{3}{*}{$\begin{array}{l}\text { Pinus contorta } \\
\text { (NW USA) }\end{array}$} & Young & 0.87 & 5.35 & 10.05 & 3.08 & 1.34 & 1.37 & 0.08 & 0.05 & 0 & 0 \\
\hline & Middle-age & 1.92 & 6.14 & 8.79 & 6.8 & 3.76 & 2.97 & 0.55 & 0.12 & 0.02 & 0 \\
\hline & Mature & 0.91 & 5.3 & 13.96 & 7.23 & 4.15 & 3.04 & 1.9 & 0.29 & 0.09 & 0 \\
\hline
\end{tabular}
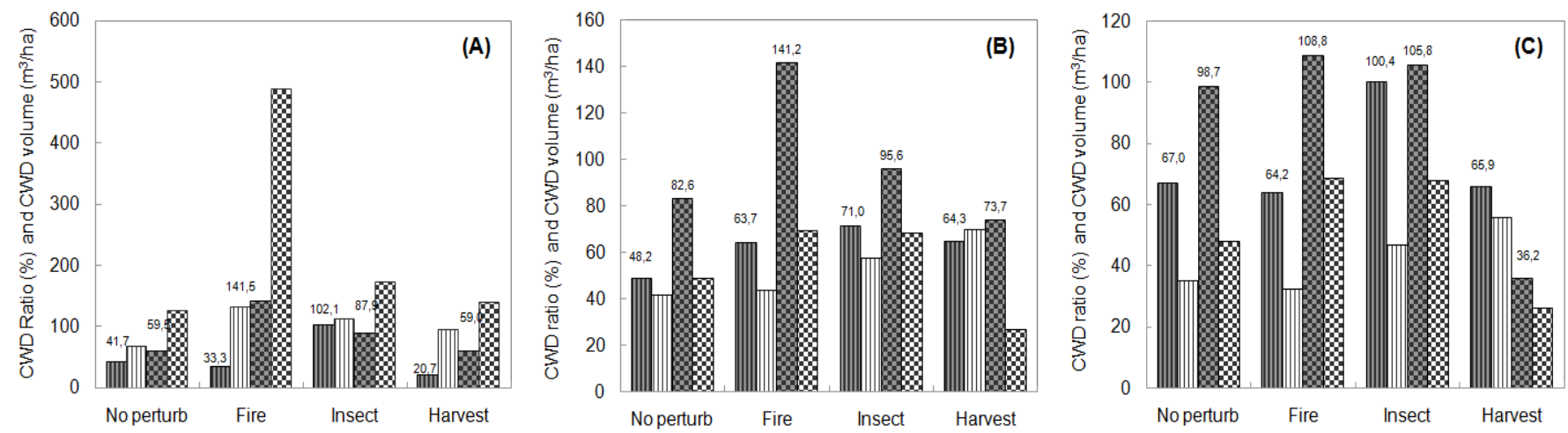

Fig. 3 - CWD ratio and volume by age class in NW USA ecosystems. Estimated ratios of CWD to live tree volume (grey bars) and CWD volumes (white bars) in young (A), middle-age (B) and mature stands (C) by disturbance type in Pinus ponderosa (line patterns) and Pinus contorta (dotted patterns) ecosystems in NW USA. 
Fig. 4 - Log volume in disturbed and undisturbed stands in NW Russia. Estimated log volume in undisturbed stands and in stands after windthrow disturbance in NW Russia

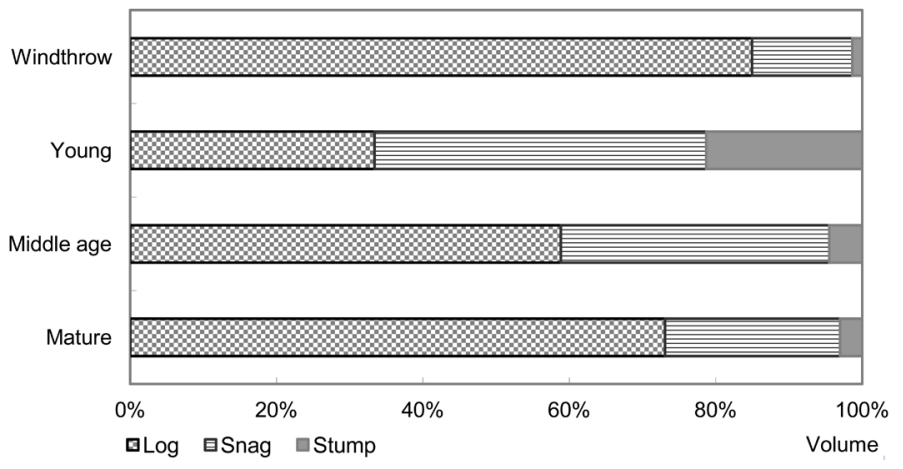

from the 3 plots affected by windthrow in NW Russia showed an average log, snag and stump volume of $162.72 \mathrm{~m}^{3} \mathrm{ha}^{-1}, 26.25$ and $2.62 \mathrm{~m}^{3} \mathrm{ha}^{-1}$, respectively. In these plots, log volume after windthrow disturbance accounted for more than $80 \%$ of total CWD (Fig. 4).

Finally, we estimated the volume of woody debris with diameters between 7.5 and $10 \mathrm{~cm}$ in NW Spain and NW USA in order to ascertain the importance of the smallest CWD pieces with respect to total volume. This class constituted $1.9 \%$ and $3.4 \%$ of total CWD in the ponderosa and lodgepole pine ecosystems of NW USA, respectively, and $6 \%$ of total CWD volume in Spain.

\section{Discussion}

In this study, we quantified and compared amounts of coarse woody debris (snags, logs and stumps) in four different pine ecosystems from three different geographical regions with distinct site conditions, forest histories and legacies, in order to understand the spatial and temporal distribution of dead wood under different forest management regimes.

The amount of dead wood varied greatly among the different pine ecosystems, but the distribution of CWD among decay classes and stand age are consistent with other studies of CWD stores. In northern Europe, Siitonen et al. (2000) found $14 \mathrm{~m}^{3} \mathrm{ha}^{-1}$ of CWD in mature stands (dominant spruces $<120$ years old) and $22 \mathrm{~m}^{3} \mathrm{ha}^{-1}$ in over-mature stands $(>120$ years old) in southern Finland. Stand history, successional stage and exogenous disturbances in individual stands were the explanatory factors for CWD variation. In the USA, Spetich et al. (1999) found $30 \mathrm{~m}^{3} \mathrm{ha}^{-1}$ CWD in mid-western secondgrowth forests. In the Pacific Northwest, Spies et al. (1988) reported higher values for Douglas fir: $423 \mathrm{~m}^{3} \mathrm{ha}^{-1}$ mean CWD volume for young stands (age 65), $250 \mathrm{~m}^{3} \mathrm{ha}^{-1}$ for mature forests (age 121), and $534 \mathrm{~m}^{3} \mathrm{ha}^{-1}$ for old-growth forests (age 404). Results from the present study for the average CWD mass of Pinus contorta (28.84 $\mathrm{Mg} \mathrm{ha}^{-1}$ ) fell within the range identified by Tinker \& Knight (2000) for undisturbed Pinus contorta stands in Wyoming. Finally, our results are in agreement with those of several studies of managed Mediterranean forests. Relatively low CWD estimates of less than $25 \mathrm{~m}^{3} \mathrm{ha}^{-1}$ have been reported in France (Vallauri et al. 2003), Turkey (Atici et al. 2008) and Italy (Motta et al. 2006, Lombardi et al. 2008). Higher values were observed in unmanaged forest or older stands (Marage \& Lemperiere 2005, Lombardi et al. 2010).

The distribution of CWD by decay class is important, because decay influences wood density and consequent carbon and nutrient content. Though Linder et al. (1997) observed large amounts of CWD in decay classes 4 and 5 in stands dominated by Scots pine in northern Sweden, our results are more in line with those of other studies in which the greatest amount of CWD was found in the intermediate decay classes (Harmon et al. 1986, Spetich et al. 1999, Lombardi et al 2008).

The results of this study indicate that logs are more abundant than snags, a finding that corroborates other studies (Krankina et al. 2002). In considering the benefits for nature conservation, Butler \& Schlaepfer (2004) suggested that snags should account for at least $50 \%$ of CWD volume in managed forests, because they provide a critical habitat for many species of cavity-nesting birds (Davis 1983, Harmon et al. 1986, Jakoby et al. 2010). The relatively lower proportion of snags found in all regions studied may reflect the transitory nature of this component. The number of snags can increase temporarily after a period of increased tree mortality, but they eventually fall over and become downed logs. To promote biodiversity, the proportion, size and longevity of snags should be taken into consideration in developing forest management guidelines (Jakoby et al. 2010).

A review of north American forest structure literature suggests a "U-shaped" distribution of CWD volume, mass, and density as a function of stand age. In other words, CWD is greatest after disturbance in very and increases slightly in mature stands, as tree mortality increases (Harmon et al. 1986, Spies et al. 1988). Our results only support those findings in Scots pine ecosystems in young stands, decreases in developing stands
NW Russia, where log volume in mature stands was more than double that of middleage stands, and log volume in young stands was more than eight times greater. This pattern was less apparent in the other three pine ecosystems, where different mechanisms (partial disturbance, prior management history) affected CWD distribution during stand development. In NW USA, the legacy of disturbance in the 10 years prior to the study determined CWD distribution across age classes. In ponderosa pine, the large amount of CWD could be related to the combination of drought and bark beetle plague in the early 1990s (Laudenslayer 2005). Though fire is historically the most common mortality agent in ponderosa pine forests, its suppression also resulted in greater accumulation of dead wood (Hessburg et al. 2005). Fire disturbance in lodgepole pine systems led to high CWD levels and a high ratio of dead to live wood volume in young stands. Tinker \& Knight (2000) showed that burned stands contained more than twice the amount of CWD than clear cut stands, largely due to the removal of live trees in harvested stands and the presence of snags in burned stands. The results of the present study also indicated that the proportion of logs vs. snags in stands with fire disturbances varied across the age classes. While the volume of logs $\left(84.58 \mathrm{~m}^{3} \mathrm{ha}^{-1}\right)$ and snags $\left(56.91 \mathrm{~m}^{3} \mathrm{ha}^{-1}\right)$ was similar in young stands, logs dominated the total CWD volume $\left(120.61 \mathrm{~m}^{3} \mathrm{ha}^{-1}\right) v s$. snag volume $\left(20.44 \mathrm{~m}^{3} \mathrm{ha}^{-1}\right)$ in middle-age stands.

Despite the small sample size, results from the NW Russia pine ecosystem showed that windthrow disturbance can create a high volume of CWD in a stand. Finally, harvesting can produce drastic changes in CWD quantity and quality. Tree removal decreases the CWD input and harvesting can affect wood pools indirectly through the fragmentation of decaying ground wood caused by machinery (Ranius et al. 2003). In NW Spain, thinning could have a significant effect on CWD amounts in young stands, where higher $\log$ and stump volumes were found in thinned stands, and where logging waste such as crown debris or pruning residues is commonly left on the ground.

Comparing CWD estimates from different studies requires caution due to variations in field measurement methods, plot selection, the area of the region studied and calculation procedures among studies (Fridman \& Walheim 2000, Grove 2001). One limitation of this study is that the sampling methods, designs and minimum piece sizes in the three regions were not exactly the same, though they all are standard procedures for sampling CWD in different parts of the world. While a common method for sampling CWD would be ideal, researchers argue that no unique method can be adopted for all forest types due to differences in forest structure, resea- 
rch objectives and resources (e.g., Woldendorp et al. 2004). There is also disagreement regarding the definition of the different CWD components. For example, Woodall et al. (2009) surveyed the methods used in the National Forest Inventories of 30 countries that sample CWD. They found that "the definitions of down woody (DW) variables varied among countries that inventory DW. Common minimum diameters at breast height for standing dead trees were $5,7,10$, and $12 \mathrm{~cm}$." They reported that $33 \%$ of the countries used a minimum diameter of 7.0 to $7.6 \mathrm{~cm}$ and $27 \%$ used $10 \mathrm{~cm}$. They also noted that the $7.5 \mathrm{~cm}$ threshold is very close to 3 inches, the cut-off measurement used to differentiate between fine and heavy fuels in fire behavior models. In this study, NW Spain and NW USA used a minimum diameter threshold of approximately $7.5 \mathrm{~cm}$, while NW Russia used $10 \mathrm{~cm}$. Therefore, we would expect the estimated CWD volume in NW Russia to be somewhat less than if a 7.5 $\mathrm{cm}$ threshold had been used. However, the number of small pieces and their contribution to total volume and biomass resulted in a very small difference that does not significantly alter the results and conclusions of this study.

The study shows that stand histories affect amounts of CWD, legacy wood and distribution relative to live volume. Forest management and response after natural disturbance or harvesting activities have a great influence on CWD quantity and quality in a forest ecosystem. After disturbances, logging residues and snags may be removed to avoid the outbreak of bark beetle and other insect populations that could damage living trees. After commercial thinning, harvested trees are also removed because the available technology and demand for wood has resulted in greater utilization of smaller and poorer quality trees. Reduction of CWD can reduce forest health risks, but can also contribute to a decline in biological diversity and nutrient cycling. The characterization of CWD amounts and distribution can inform forest management decisions by improving understanding of how diverse conditions, beyond those that might be encountered in a single location, can affect CWD dynamics. The mature stands without disturbances in NW USA allowed us to examine deadwood accumulation in a context similar to primary forest or forest with stand development stages approaching naturalness. In contrast, CWD was scarce in the short-rotation, managed forest sites of NW USA and NW Spain, where natural stage development was interrupted early on (Duvall \& Grigal 1999, Vandekerkhove et al. 2009).

Managers need to know how much CWD to leave or create in a stand. Here, we have examined deadwood accumulation in stands ranging from short rotation managed forest to those approaching levels of naturalness. The results can inform guidelines for prescribing adequate levels of CWD in terms of density, size, and amount in different decomposition classes, as well as for attaining optimal response after disturbances. The relevance of such information cannot be understated in the current context of forest management linked to intensive silviculture. The significant role of dead wood in carbon pooling linked to biodiversity is becoming clearer and competes with a growing interest in harvesting logging residues for energy production.

\section{Conclusions}

Four pine ecosystems were compared in three regions with different site conditions, forest histories and legacies. The results of this paper show that the quantity of dead wood varies greatly according to pine ecosystem and stand age class. The large differences in CWD stores and successional patterns appear to correspond to variations in natural conditions, management practices, legacy and disturbance history in the regions studied. Coarse woody debris ranged from $3.76 \mathrm{~m}^{3} \mathrm{ha}^{-1}$ (1.55 Mg ha $\left.{ }^{-1}\right)$ for Pinus spp. NW Spain to $24.86 \mathrm{~m}^{3} \mathrm{ha}^{-1}\left(6.69 \mathrm{Mg} \mathrm{ha}^{-1}\right)$ for Pinus sylvestris in NW Russia to 55.35 $\mathrm{m}^{3} \mathrm{ha}^{-1}\left(20.38 \mathrm{Mg} \mathrm{ha}^{-1}\right)$ for Pinus ponderosa and $77.04 \mathrm{~m}^{3} \mathrm{ha}^{-1}\left(28.04 \mathrm{Mg} \mathrm{ha}^{-1}\right)$ for Pinus contorta, both in NW USA.

The common assumption of a "U-shaped" CWD accumulation pattern was not supported in NW USA forest ecosystems. Fire and insect damage disturbances affected CWD amounts in all age classes in both Pinus contorta and Pinus ponderosa forests. Dead to live wood volume ratios were found to be closely related to natural and human perturbations.

\section{Acknowledgments}

We want to express our gratitude to Becky Fasth, Mark Harmon, Mikhail Yatkov, Susan Morré and Valentín Pando for providing help with data support, analysis and the English language. This work was made possible through the INTERREG III B FORSEE project financed by the European Union and through the University of Valladolid grant program. The authors thank Andrea Blanch for her helpful English review and the anonymous referees for their valuable comments on the manuscript.

\section{References}

Angelstam PK (1998). Maintaining and restoring biodiversity in European boreal forests by developing natural disturbance regimes. Journal of Vegetation Science 9: 593-602. - doi: 10.2307/ 3237275

Atici E, Colak AH, Rotherham ID (2008). Coarse dead wood volume of managed oriental Beech (Fagus orientalis Lipsky) stands in Turkey.
Forest systems 17 (3): 216-227. [online] URL: http://www.inia.es/gcontrec/pub/216-227

Coarse_Dead_1229946186781.pdf

Bechtold WA, Scott CT (2005). The forest inventory and analysis plot design. In: "The enhanced forest inventory and analysis program" (Bechtold WA, Patterson PL eds). Gen. Tech. Rep. SRSGTR-80, USDA Forest Service, Asheville, NC, USA, pp. 27-42.

Butler R, Schlaepfer R (2004). Dead wood in managed forests: how much is enough? Schweizerische Zeitschrift für Forstwesen 155 (2): 31-37. - doi: 10.3188/szf.2004.0031

Carlyle JC (1995). Nutrient management in a Pinus radiata plantation after thinning: the effect of thinning and residues on nutrient distribution, mineral nitrogen fluxes, and extractable phosphorus. Canadian Journal of Forest Research 25: 1278-1291. - doi: 10.1139/x95-141

Davis JW (1983). Snags are for wildlife. In: "Proceedings of the symposium on snag habitat management" (Davis JW, Goodwin GA, Ockenfels RA eds). Gen. Tech. Rep. RM-99, USDA Forest Service, Flagstaff, Arizona, USA, pp. 4-9.

Duvall MD, Grigal DF (1999). Effects of timber harvesting on coarse woody debris in red pine forests across the Great Lakes states, USA. Canadian Journal of Forest Research 29 (12): 19261934. - doi: 10.1139/x99-158

DeBell DS, Curtis RC, Harrington CA, Tappeiner JC (1997). Shaping stand development through silvicultural practices. In: "Creating forestry for the $21^{\text {st }}$ century (Kohm LA, Franklin JF eds). The science of ecosystem management. Island Press, Washington, DC, USA, pp. 141-151.

deMaynadier PG, Hunter MLJr (1995). The relationship between forest management and amphibian ecology: a review of the North American literature. Environmental Research 3: 230-261.

DGCN (1996). Segundo inventario forestal nacional completo: 1986-1996. Parques Nacionales, Madrid, Spain. [in Spanish]

Donnegan J, Campbell S, Azuma D (2008). Oregon's forest resources, 2001-2005. Gen. Tech. Rep. PNW-GTR-765, USDA Forest Service, Portland, Oregon,USA, pp. 186.

Esseen PA, Ehnstrom B, Sjoberg K, Ericson L (1997). Boreal forests. In: "Boreal ecosystems and landscapes: structures, processes and conservation of biodiversity" (Hanson L ed). Ecological Bulletins 46, pp. 16-47. [online] URL: http://www.jstor.org/stable/20113207

Forsee Project (2005). Proyecto FORSEE (20) INTERREG III B Espacio atlántico [online] URL: http://www.iefc.net/index.php?affiche_page= projet_FORSEE

Franklin JF, Dyrness CT (1973). Natural vegetation of Oregon and Washington. General Technical Report PNW-8, USDA Forest Service, Portland, Oregon, USA, pp. 417.

Fridman J, Walheim M (2000). Amount, structure, and dynamics of dead wood on managed forestland in Sweden. Forest Ecology and Management 131: 23-36. - doi: 10.1016/S0378-1127 (99)00208-X

Goodburn JM, Lorimer CG (1998). Cavity trees 
and coarse woody debris in old-growth and managed northern hardwood forests in Wisconsin and Michigan. Canadian Journal of Forest Research 28: 427-438. - doi: 10.1139/x98-014

Green P, Peterken GF (1997). Variation in the amount of dead wood in woodlands of the Lower Wye Valley, UK in relation to the intensity of management. Forest Ecology and Management 98: 229-228. - doi: 10.1016/S0378-1127(97) 00106-0

Grove SJ (2001). Extend and composition of dead wood in Australian lowland tropical rainforest with different management histories. Forest Ecology and Management 154: 35-53. - doi 10.1016/S0378-1127(00)00618-6

Harmon ME, Franklin JF, Swanson FJ, Sollins P, Gregory SV, Lattin JD, Anderson NH, Cline SP, Aumen NG, Sedell JR, Lienkaemper GW, Cromack K Jr, Cummins KW (1986). Ecology of coarse woody debris in temperate ecosystems. Advances in Ecological Research 15: 133-302. doi: 10.1016/S0065-2504(08)60121-X

Harmon M, Sexton J (1996). Guidelines for measurements of woody detritus in forest ecosystems. Publication no. 20, US/LTER Network Office, University of Washington, Seattle, WA, USA.

Harmon ME, Woodall CW, Fasth B, Sexton J (2008). Woody detritus density and density reduction factors for tree species in the United States: a synthesis. Gen. Tech. Rep. NRS-GTR29, USDA Forest Service, Northern Research Station, Newtown Square, Pennsylvania, USA, pp. 65.

Herrero C, Pando V, Bravo F (2010). Modelling coarse woody debris in Pinus spp. plantations. A case study in Northern Spain. Annals of Forest Science 67: 708-716. - doi: 10.1051/forest/ 2010033

Hessburg PF, Agee JK, Franklin JF (2005). Dry forests and wildland fires in the inland Northwest USA: contrasting the landscape ecology of the pre-settlement and modern eras. Forest Ecology and Management 211: 117-139. - doi 10.1016/j.foreco.2005.02.016

Hyvonenn R, Olsson AB, Lundkvist H, Staaf H (2000). Decomposition and nutrient release from Picea abies (L.) Karst. and Pinus sylvestris L. logging residues. Forest Ecology and Management 126: 97-112. - doi: 10.1016/S0378-1127 (99)00092-4

Jakoby O, Rademacher C, Grimm V (2010). Modelling dead wood islands in European beech forests: how much and how reliably would they provide dead wood? European Journal of Forest Research 129: 659-668. - doi: 10.1007/s10342010-0366-3

Krankina ON, Harmon ME (1995). Dynamics of the dead wood carbon pool in Northwestern Russian boreal forest. Water Air and Soil Pollution 82 (1/2): 227-238. - doi: 10.1007/BF01182836

Krankina ON, Harmon ME, Griazkin AV (1999). Nutrient stores and dynamics of woody detritus in a boreal forest: modelling potential implications at the stand level. Canadian Journal of Forest Research 29: 20-32. - doi: 10.1139/x98-
162

Krankina ON, Harmon ME, Kukuev YA, Treyfeld RF, Kashpor NN, Kresnov VG, Skudin VM, Protasov NA, Yatskov M, Spycher G, Povarov ED (2002). Coarse woody debris in forest regions of Russia. Canadian Journal of Forest Research 32: 768-778. - doi: 10.1139/x01-110

Laudenslayer WF (2005). Effects of site on the demographics of standing dead trees in eastside pine forests. In: Proceedings of the Symposium "Ponderosa pine: issues, trends, and management" (Ritchie MW, Youngblood A, Maguire DA eds). Gen. Tech. Rep. PSW-GTR-198, USDA Forest Service, California, USA, pp. 171181.

Linder P, Elfving B, Zackrisson O (1997). Stand structure and successional trends in virgin boreal forest reserves in Sweden. Forest Ecology and Management 98: 17-33. - doi: 10.1016/S03781127(97)00076-5

Lombardi F, Lasserre B, Tognetti R, Marchetti M (2008). Deadwood in relation to stand management and forest type in central Apennines (Molise, Italy). Ecosystems 11: 882-894 - doi: 10.1007/s10021-008-9167-7

Lombardi F, Chirici G, Marchetti M, Tognetti R, Lasserre B, Corona P, Barbati A, Ferrari B, Di Paolo S, Giuliarelli D, Mason F, Iovino F, Nicolaci A, Bianchi L, Maltoni A, Travaglini D (2010). Deadwood in forest stands close to oldgrowthness under Mediterranean conditions in the Italian Peninsula. Italian Journal of Forest and Mountain Environments 65: 481-504. - doi: 10.4129/ifm.2010.5.02

Marage D, Lemperiere G (2005). The management of snags: a comparison in managed and unmanaged ancient forests of the southern French Alps. Annals of Forest Science 62: 135-142. doi: 10.1051/forest:2005005

Merganicôvá K, Merganic J (2010). Coarse woody debris carbon stocks in natural spruce forests of Babia hora. Journal of Forest Science 56: 397-405. [online] URL: http://www.agriculturejournals.cz/publicFiles/27548.pdf

McComn W, Lindenmayer D (1999). Dying, dead, and down trees. In: "Maintaining Biodiversity in Forest Ecosystems" (Malcon L, Hunter JR eds). Cambridge University Press, Cambridge, UK, pp. 335-372.

Motta R, Berretti R, Lingua E, Piussi P (2006). Coarse woody debris, forest structure and regeneration in the Valbona Forest Reserve, Panaveggio, Italian Alps. Forest Ecology and Management 235: 155-163. - doi: 10.1016/j.foreco. 2006.08.007

Oria de Rueda JA, Díez J, Rodríguez M (1996). Guía de las plantas silvestres de Palencia. Cálamo, Palencia, Spain. [in Spanish]

Ranius T, Kindvall O, Kruys N, Jonsson BG (2003). Modelling dead wood in Norway spruce stands subject to different management regimes. Forest Ecology and Management 182: 13-29. doi: 10.1016/S0378-1127(03)00027-6

SAS Institute Inc (2010). SAS/STATTM User's Guide, Relase 9.1. Cary, NC, USA.

Siitonen J, Martikainen P, Punttila P, Rauh J
(2000). Coarse woody debris and stand characteristics in mature managed and old-growth boreal mesic forests in southern Finland. Forest Ecology and Management 128: 211-225. - doi: 10.1016/S0378-1127(99)00148-6

Spetich MA, Shifley SR, Parker GR (1999). Coarse woody debris in midwestern old-growth forests. Forest Science 45: 302-313.

Spies TA, Franklin JF, Thomas TB (1988). Coarse woody debris in Douglas-fir forests of western Oregon and Washington. Ecology 69: 16891702. - doi: 10.2307/1941147

Tinker DB, Knight DH (2000). Coarse woody debris following fire and logging in Wyoming lodgepole pine forests. Ecosystems 3: 472-483. doi: $10.1007 / \mathrm{s} 100210000041$

USDA Forest Service (2007). Forest inventory and analysis program: field instructions for the annual inventory of Washington, Oregon and California. Pacific Northwest Research Station, Portland, OR, USA, pp. 172. [online] URL: [online] URL: http://www.fs.fed.us/pnw/fia/publications/fieldmanuals.shtml

Vallauri D, Andre J, Blondel J (2003). Dead wood - a typical shortcoming of managed forests. Revue Forestiere Francaise 55 (2): 99-112. - doi: $10.4267 / 2042 / 5172$

Van Wagner CE (1968). The line-intersect method in forest fuel sampling. Forest Science 14: 20-26. Vandekerkhove K, De Keersmaeker L, Menke N, Meyer P, Verschelde P (2009). When nature takes over from man. Dead wood accumulation in previously managed oak and beech woodlands in north-western and central Europe. Forest Ecology and Management 258 (4): 425-435. - doi: 10.1016/j.foreco.2009.01.055

von Oheimb G, Westphal C, Härdtle W (2007). Diversity and spatio-temporal dynamics of dead wood in a temperate near-natural beech forest (Fagus sylvatica). European Journal of Forest Research 126: 359-370. - doi: 10.1007/s10342006-0152-4

Warren WG, Olsen PF (1964). A line-intersect technique for assessing logging waste. Forest Science 10: 267-276.

Woldendorp G, Keenan RJ, Barry S, Spencer RD (2004). Analysis of sampling methods for coarse woody debris. Forest Ecology and Management 198: 133-148. - doi: 10.1016/j.foreco.2004.03. 042

Woodall CW, Monleon VJ (2008). Sampling protocol, estimation, and analysis procedures for the down woody materials indicator of the FIA Program $\left(2^{\text {nd }}\right.$ edition $)$. Gen. Tech. Rep. NRS-GTR22, USDA Forest Service, St. Paul, MN, USA.

Woodall CW, Rondeux J, Verkerk PJ, Stahl G (2009). Estimating dead wood during national forest inventories: a review of inventory methodologies and suggestions for harmonization. Environmental Management 44: 624-631. - doi: 10.1007/s00267-009-9358-9

Yatskov M, Harmon ME, Krankina ON (2003). A chronosequence of wood decomposition in the boreal forests of Russia. Canadian Journal of Forest Research 33: 1211-1226 - doi: 10.1139/ x03-033 